\title{
Artikel
}

\section{Vernietiging van de overeenkomst bij een oneerlijke handelspraktijk; een hanteerbare sanctie?}

Prof. mr. drs. C.M.D.S. Pavillon en mr. dr. L.B.A. Tigelaar*

\section{Inleiding}

Een handelaar die gebruikmaakt van een oneerlijke handelspraktijk jegens een consument pleegt een onrechtmatige daad (art. 6:193b lid 1 van het Burgerlijk Wetboek (BW)). Voorbeelden zijn het voeren van een keurmerk terwijl de handelaar daarbij niet is aangesloten, of het voorstellen van wettelijke rechten als een onderscheidend kenmerk van het aanbod. Oneerlijke praktijken zijn er veelal op gericht de consument te overtuigen een overeenkomst aan te gaan door op onheuse wijze zijn wilsvorming te beïnvloeden. Het verbaast daarom niet dat ten tijde van de omzetting van de Richtlijn oneerlijke handelspraktijken ${ }^{1}$ zowel in het parlementaire debat als in de literatuur de oneerlijke handelspraktijken in verband zijn gebracht met de wilsgebreken. ${ }^{2}$ Misleidende handelspraktijken zijn gelinkt aan de wilsgebreken dwaling en bedrog, en agressieve handelspraktijken

* $\quad$ Prof. mr. drs. C.M.D.S. Pavillon is hoogleraar privaatrecht, in het bijzonder consumentenrecht aan de Rijksuniversiteit Groningen. Mr. dr. L.B.A Tigelaar is universitair docent verbintenissenrecht aan de Rijksuniversiteit Groningen. Onze namen zijn weergegeven in alfabetische volgorde.

1. Richtlijn 2005/29/EG van het Europees Parlement en de Raad van 11 mei 2005 betreffende oneerlijke handelspraktijken van ondernemingen jegens consumenten op de interne markt (PbEU 2005, L 149/22).

2. Kamerstukken II 2006/07, 30928, 3, p. 9 (MvT); Kamerstukken II 2006/07, 30928, 8, p. 17-19; D.W.F. Verkade, Oneerlijke handelspraktijken jegens consumenten, Deventer: Kluwer 2016, nr. 73b; R. Steennot \& P. Geerts, De implementatie van de Richtlijn oneerlijke handelspraktijken in België en Nederland, TPR 2011, p. 762-765; W.H. van Boom, Inpassing en handhaving van de Wet oneerlijke handelspraktijken, TvCH 2008/1, p. 5 en 6. vertonen gelijkenis met de wilsgebreken bedreiging en misbruik van omstandigheden. Met de invoering van de vernietigingsgrond in artikel 6:193j lid $3 \mathrm{BW}$ sluit de regeling oneerlijke handelspraktijken (hierna: regeling $\mathrm{OHP}$, neergelegd in afdeling 6.3.3A BW) qua rechtsgevolg sinds 2014 naadloos aan op de wilsgebrekenregeling. Deze vernietigingssanctie doet ook recht aan de voor de hand liggende wens van de misleide consument om van de overeenkomst 'af te komen'.

Toepassingen van artikel 6:193j lid 3 BW zijn evenwel buitengewoon schaars in de gepubliceerde rechtspraak. ${ }^{4}$ Dit doet twijfelen aan de hanteerbaarheid van de sanctie in de praktijk. In deze bijdrage wordt onderzocht hoe hanteerbaar, in de zin van toegankelijk en gebruiksvriendelijk, de vernietigingsgrond uit artikel 6:193j lid 3 BW eigenlijk is. Dit doen wij door een zestal uitspraken te analyseren waarin de sanctie is ingeroepen en/of toegepast. ${ }^{5}$ Ten eerste bezien wij wie van de eiser, verweerder of de rechter het initiatief nam voor de toetsing aan

3. W.H. van Boom, Oneerlijke handelspraktijk is onrechtmatige daad. Maar wat schieten we daar mee op?, NTBR 2008/3, p. 125.

4. Of consumenten vaak buitengerechtelijk vernietigen is ons niet bekend, maar lijkt ons niet aannemelijk.

5. Het gaat om de volgende zes uitspraken: Rb. Noord-Holland 13 september 2017, ECLI:NL:RBNHO:2017:7627 (Koop percelen II); Rb. Amsterdam 5 september 2017, ECLI:NL:RBAMS:2017:6552 (Telefoonabonnement); Rb. Noord-Holland 30 november 2016, ECLI:NL:RBNHO:2016:10650 (Koop percelen I); Rb. Midden-Nederland 30 september 2015, ECLI:NL:RBMNE:2015:6985 (Hijama-therapeut); Rb. Noord-Holland 13 november 2014, ECLI:NL:RBNHO:2014:12536 (Pseudo Focwa-lid); Rb. Noord-Holland 17 september 2014, ECLI:NL:RBNHO:2014:9422 (Motorverzekering). De laatste drie uitspraken zijn besproken door R. van Neck \& A.A.H. M. van der Wijst, De vernietigingssanctie uit de Wet oneerlijke handelspraktijken toegepast in de praktijk, Jutd 2015/23, p. 5-8. 
de regeling OHP respectievelijk artikel 6:193j lid 3 BW (par. 2). ${ }^{6}$ Ten tweede bekijken wij wat de vereisten zijn voor een geslaagd beroep op artikel 6:193j lid $3 \mathrm{BW}$ (par. 3). Ten derde gaan wij na wat de rechtsgevolgen zijn van een geslaagd beroep op de vernietigingsgrond (par. 4). De rechtspraakanalyse sluiten wij af met het antwoord op de hanteerbaarheidsvraag (par. 5).

\section{Het initiatief voor de toepassing van de regeling OHP en bijbehorende} sanctie

\subsection{Het initiatief ligt volledig bij de eiser}

In twee van de zes geraadpleegde uitspraken doet de eiser zelf een beroep op artikel 6:193j lid $3 \mathrm{BW}{ }^{7}$ In de eerste zaak koopt een kweker percelen van Groza BV via vastgoedbemiddelaar Aktua Vastgoed BV. ${ }^{8}$ De kweker doet een beroep op de regeling OHP en op de vernietigingsgrond. ${ }^{9}$ In de tweede zaak koopt iemand die anderszins actief is in de agrarische sector via Aktua percelen van Groza. ${ }^{10}$ Ook die koper roept de vernietiging in van de overeenkomst op grond van artikel 6:193j lid 3 BW. ${ }^{11}$ Opvallend is dat in beide gevallen geen sprake is van een consument en de richtlijn dus niet van toepassing is (zie par. 3.1.1). In de overige vier zaken is wel sprake van een consument.

\subsection{Het initiatief ligt deels bij de rechter}

In drie van de zes uitspraken is het niet de consument, maar de rechter die de vernietigingssanctie van artikel 6:193j lid $3 \mathrm{BW}$ te berde brengt. ${ }^{12}$ In deze gevallen toetst de rechter dus niet ambtshalve aan de regeling, maar vult hij de rechtsgronden aan door de bijbehorende sanctie ambtshalve toe te passen. ${ }^{13}$ In de eerste zaak vordert de consument de vernietiging van een opleidingsovereenkomst tot Hijama-therapeut, ${ }^{14}$ maar is onduidelijk op grond waarvan hij dit doet. De consument beroept zich behalve op artikel 6:193b lid $1 \mathrm{BW}$ ook op dwaling en bedrog. De rechter vult deze eis aan

6. Zie hierover ook par. 2.7 van het binnenkort te verschijnen rapport Ambtshalve toetsing III.

7. Koop percelen I, r.o. 4.11 en Koop percelen II, r.o. 4.17.

8. Koop percelen I, r.o. 2.1-2.7.

9. Koop percelen I, r.o. 4.2. Overigens komt de vraag of de kweker wel consument is in deze uitspraak niet aan de orde.

10. Koop percelen II, r.o. 2.1-2.18

11. Koop percelen II, r.o. 4.8 en 4.17

12. Rb. Noord-Holland 17 september 2014, ECLI:NL:RBNHO:2014:9422 (Motorverzekering); Rb. Noord-Holland 13 november 2014, ECLI:NL:RBNHO:2014:12536 (Pseudo Focwa-lid); Rb. Midden-Nederland 30 september 2015, ECLI:NL:RBMNE:2015:6985 (Hijama-therapeut).

13. Vgl. HvJ EU 3 oktober 2013, C-32/12, ECLI:EU:C:2013:637 (Duarte Hueros); zie ook A.G.F. Ancery \& C.M.D.S. Pavillon, De rechterlijke lijdelijkheid in rook opgegaan? De ambtshalve toepassing van de consumentenkoopregels nader toegelicht, MvV 2015/ 9, p. 244-245.

14. Bij deze therapie wordt een kop op bepaalde punten op de huid geplaatst en vacuüm getrokken. met artikel 6:193j lid 3 BW..$^{15}$ De rechter geeft aan dat vaststaat dat de opleiding op het moment van de contractssluiting niet beschikte over twee van de door haar gevoerde keurmerken. Dit levert een misleidende handelspraktijk op in de zin van artikel 6:193g anhef en sub b BW. ${ }^{16}$ Dit maakt volgens de rechter dat de consument de als gevolg van die praktijk tot stand gekomen overeenkomst kan vernietigen. ${ }^{17}$ Dat de consument artikel 6:193j lid 3 BW niet expliciet lijkt te hebben ingeroepen, doet er niet toe.

In de tweede en derde zaak is de consument verweerder. In beide zaken vordert de consument in reconventie een ander rechtsgevolg dan de vernietiging van de overeenkomst. In de tweede zaak gaat het om schade aan een motor die is ontstaan tijdens een motorreis door Amerika. ${ }^{18}$ De consument voert het verweer dat de reisorganisatie in haar reclame misleidende informatie heeft gegeven. De kantonrechter vat dit verweer op als een beroep op de misleidende handelspraktijk of de misleidende omissie ${ }^{19}$ en gaat hierin mee. ${ }^{20}$ De consument beroept zich voorts op de beperkende werking van de redelijkheid en billijkheid en dit vertaalt de kantonrechter naar een beroep op vernietiging ex artikel 6:193j lid 3 BW. Hij onderbouwt deze beslissing door erop te wijzen dat hij rechtsgronden ambtshalve dient aan te vullen. ${ }^{21}$

In de derde zaak wil de consument de koop van een auto ontbinden wegens non-conformiteit. ${ }^{22}$ In het kader van het beroep op artikel 7:17 BW voert de consument aan dat de garage zich ten onrechte heeft voorgedaan als een bij de FOWCA aangesloten garage en dat sprake is van een misleidende handelspraktijk. ${ }^{23}$ Een beroep op vernietiging doet hij kennelijk niet. De kantonrechter is van oordeel dat sprake is van zowel een tekortkoming in de nakoming als $^{24}$ een misleidende handelspraktijk. ${ }^{25}$ Omdat het FOWCA-lidmaatschap de consument heeft bewogen om de auto te kopen, is de overeenkomst volgens de rechter vernietigbaar op grond van artikel $6: 193 j$ lid $3 \mathrm{BW} .^{26} \mathrm{Hij}$ gaat echter niet over tot vernietiging, maar ontbindt de overeenkomst zoals gevorderd op grond van artikel 7:21 BW.

15. Rb. Midden-Nederland 30 september 2015, ECLI:NL:RBMNE: 2015:6985 (Hijama-therapeut).

16. Hijama-therapeut, r.o. 4.3

17. Hijama-therapeut, r.o. 4.4

18. Rb. Noord-Holland 17 september 2014, ECLI:NL:RBNHO:2014:9422 (Motorverzekering), r.o. 9 en 10.

19. Motorverzekering, r.o. 13 en 14.

20. Motorverzekering, r.o. 16.

21. Motorverzekering, r.o. 17. De 'ambtshalve vernietiging' staat op gespannen voet met ons nietighedenstelsel. Sinds het arrest Heesakkers/Voets van de Hoge Raad wordt de ambtshalve vernietiging van algemene voorwaarden op grond van art. 6:233 sub a BW erkend: HR 13 september 2013, ECLI:NL:HR:2013:691, r.o. 3.7.3. In casu is evenwel geen gebruik gemaakt van de regeling inzake oneerlijke bedingen, maar van de regeling OHP (hierna par. 3.1.2)

22. Rb. Noord-Holland 13 november 2014, ECLI:NL:RBNHO:2014:12536 (Pseudo Focwa-lid).

23. Pseudo Focwa-lid, r.o. 2-8 en 21

24. Pseudo Focwa-lid, r.o. 14-19.

25. Pseudo Focwa-lid, r.o. 21.

26. Pseudo Focwa-lid, r.o. 21. 
Het is de vraag of de rechter ultra petita moet gaan om de consument effectief tegen oneerlijke handelspraktijken te beschermen. Het effectiviteitsbeginsel vergt in de situatie waarin de consument, bij een beroep op de regeling OHP, nalaat om de bijbehorende vernietigingssanctie in te roepen, geenszins dat het nationale procesrecht terzijde wordt geschoven. Zo kan de rechter de consument de mogelijkheid bieden om ex artikel 130 van het Wetboek van Burgerlijke Rechtsvordering (Rv) zijn vordering te wijzigen. ${ }^{27}$ Maar wat als sprake is van een oneerlijke handelspraktijk en de consument helemaal geen beroep doet op de hem beschermende regeling, omdat hij niet op de hoogte is van die regeling of niet komt opdagen?

\subsection{Het initiatief ligt volledig bij de rechter}

\subsubsection{Europese achtergrond ambtshalve toetsing}

Er bestaat geen Europese rechtspraak die de ambtshalve toetsing aan de Richtlijn OHP verplicht stelt. De richtlijn voorziet zelf niet in contractuele sancties en laat de nationale regels inzake rechtshandeling en overeenkomst onaangeroerd (art. 3 lid 2 Richtlijn OHP). Zij verschaft geen individuele rechten aan consumenten en $A-G$ Wahl wees er recent op dat de Richtlijn OHP zich in dit opzicht onderscheidt van de Richtlijn oneerlijke bedingen. ${ }^{28}$ Het Hof van Justitie van de Europese Unie (HvJ EU) heeft zich nog niet gebogen over de vraag of het bestaan van een oneerlijke handelspraktijk ambtshalve moet worden vastgesteld, zoals ook een oneerlijk beding of de schending van een informatieverplichting door een kredietverstrekker ${ }^{29}$ ambtshalve moet worden 'opgespoord' door de rechter. Het antwoord op deze vraag luidt onzes inziens om drie redenen bevestigend:

- De ambtshalve toetsing aan de regeling OHP geschiedt in overeenstemming met het doeltreffendheids- en gelijkwaardigheidsbeginsel. ${ }^{30} \mathrm{Nu}$ de Nederlandse wetgever ervoor koos een vernietigingssanctie in het leven te roepen, moet deze sanctie aan artikel 13 Richtlijn OHP voldoen. Dit artikel vergt dat doeltreffende, evenredige en afschrikwekkende sancties worden gesteld op het gebruik van oneerlijke handelspraktijken. Aan die drievoudige eis kan pas worden voldaan als komt vast te staan dat sprake is van een oneerlijke praktijk. Beroept de consument zich

27. HvJ EU 3 oktober 2013, C-32/12, ECLI:EU:C:2013:637 (Duarte Hueros), TvCH 2014/3, m.nt. A.G.F. Ancery, onder 8.

28. Conclusie A-G Wahl van 21 maart 2018 in zaak C-109/17 (Bankia), ECLI:EU:C:2018:201, nr. 56-59. Anders: A.S. Hartkamp, Ambtshalve toepassing van Europees consumentenrecht. Een nieuw hoofdstuk: de richtlijn consumentenkoop, AAe maart 2015, p. 225-226

29. HvJ EU 4 oktober 2007, C-429/05, NJ 2008/37 (Rampion); F.J.P. Lock, De verdeling van stelplicht en bewijslast tussen de consument en de tekortschietende kredietverstrekker; een Nederlands en Europees perspectief, NTBR 2016/16, p. 118

30. HvJ EU 16 december 1976, C-45/76, Jur. 1976, p. 2043 (Comet); HvJ EU 16 december 1976, C-33/76, Jur. 1976, p. 1989 (Rewe). Als consumentenbeschermende regels van Europese origine zouden ook de regels inzake OHP worden gelijkgesteld aan regels die naar nationaal recht van openbare orde zijn. Vgl. HvJ EG 6 oktober 2009, C-40/08 (Asturcom). niet op de norm, dan wordt de bijbehorende sanctie een lege huls.

- De Hoge Raad heeft de ambtshalve toetsingsverplichting reeds uitgebreid naar nationaal recht en bijbehorende sancties (de oude regeling inzake koop op afbetaling). ${ }^{31}$ Er kunnen wat betreft die verplichting thans drie situaties worden onderscheiden: (1) de ambtshalve toetsing aan Europese regels en ambtshalve toepassing van een Europese sanctie hierop (zoals bij de Richtlijn oneerlijke bedingen), (2) de ambtshalve toetsing aan nationale regels en ambtshalve toepassing van een nationale sanctie hierop (zoals bij de oude regels inzake koop op afbetaling), en (3) de ambtshalve toetsing aan Europese regels en ambtshalve toepassing van een 'nationale' sanctie hierop (zoals bij de Richtlijn oneerlijke handelspraktijken). Om redenen van consistentie en hanteerbaarheid zou in de laatste situatie dezelfde verplichting moeten gelden als in de eerste twee.

- De Europese Commissie heeft een richtlijnvoorstel gepubliceerd waarin de invoering van civielrechtelijke remedies bij oneerlijke handelspraktijken verplicht wordt gesteld. ${ }^{32}$ De vooralsnog nationale sanctie krijgt op termijn dus een Europese achtergrond. De verplichte ambtshalve toetsing aan de norm en toepassing van deze sanctie zal dan naar wij verwachten snel worden bevestigd op Europees niveau. Hierop kan de rechter anticiperen. ${ }^{33}$

De Nederlandse wetgever heeft door de zelfgekozen civielrechtelijke sanctie ${ }^{34}$ een ambtshalve toetsingsverplichting op de Nederlands rechter 'afgeroepen'.

\subsubsection{De ambtshalve toetsing in de praktijk}

In een uitspraak van de Rechtbank Amsterdam van 5 september 2017 haalt de rechter de regeling OHP er uit eigener beweging bij en gaat hij, na de ambtshalve toetsing hieraan, over tot de ambtshalve toepassing van artikel 6:193j lid 3 BW. ${ }^{35}$ Gedaagde in deze zaak is al jaren abonnee bij T-Mobile en gaat in een van de winkels van T-Mobile een nieuw abonnement aan in de (naar later bleek) onjuiste veronderstelling dat hij deze

31. HR 12 februari 2016, ECLI:NL:HR:2016:236, r.o. 3.11.1 waarover Hartkamp in zijn annotatie bij HR 26 februari 2016, ECLI:NL:HR:2016:340, JOR 2016/116, sub 6.

32. Voorstel voor een richtlijn van het Europees Parlement en de Raad tot wijziging van Richtlijn 93/13/EEG van de Raad van 5 april 1993, Richtlijn 98/6/EG van het Europees Parlement en de Raad, Richtlijn 2005/29/EG van het Europees Parlement en de Raad, en Richtlijn 2011/83/EU van het Europees Parlement en de Raad wat betreft betere handhaving en modernisering van de regels voor consumentenbescherming in de EU, art. 1 onder 4 (m.b.t. de invoering van art. 11 bis in de Richtlijn OHP).

33. Het LOVCK gaat ook uit van een verplichte toetsing aan de regeling OHP, zo blijkt uit het binnenkort te verschijnen rapport Ambsthalve toetsing III 2018, par. 2.7.

34. Deze keuze was ten tijde van de omzetting niet vanzelfsprekend en lang niet alle lidstaten hebben die keuze ook gemaakt. Als gezegd, wil de Commissie deze lidstaten nu toch dwingen tot het treffen van civielrechtelijke sancties.

35. Rb. Amsterdam 5 september 2017, ECLI:NL:RBAMS:2017:6552 (Telefoonabonnement). 
maandelijks kan opzeggen. ${ }^{36}$ De rechter komt tot het oordeel dat hierbij sprake is geweest van een misleidende omissie. ${ }^{37}$ Verwijzend naar rechtspraak van het HvJ EU geeft hij aan dat de rechtsgevolgen van een oneerlijke handelspraktijk doeltreffend, evenredig en afschrikwekkend moeten zijn. Met het oog daarop past de rechter artikel 6:193j lid $3 \mathrm{BW}$ ambtshalve toe en concludeert hij dat het abonnement partieel wordt vernietigd. ${ }^{38}$ Getroffen zijn kennelijk (dit wordt niet expliciet benoemd) de vaste duur van de overeenkomst en de onmogelijkheid om de overeenkomst tussentijds op te zeggen, waardoor de consument rechtsgeldig heeft opgezegd.

\subsubsection{Aanknopingspunten voor ambtshalve toetsing aan afdeling 6.3.3A $\mathrm{BW}$}

In de situatie waarin geen beroep op de regeling OHP wordt gedaan (ongeacht of de consument eiser of verweerder is), moeten er wel voldoende aanknopingspunten bestaan om tot een ambtshalve toetsing aan de regeling OHP over te gaan. Pas dan dient de rechter de nodige maatregelen te treffen om de effectieve werking van de richtlijn te garanderen. Vanuit het perspectief van de partijen zijn de volgende aanknopingspunten denkbaar:

1. De ondernemer beroept zich op een beding waarover bij de consument onduidelijkheid bestaat. ${ }^{39}$ Of de consument geeft aan bepaalde informatie niet te hebben gehad of verkeerd te hebben begrepen ten tijde van de contractssluiting. ${ }^{40}$ Die onwetendheid kan voortvloeien uit - zo blijkt uit het dossier - tegenstrijdige of 'verstopte' informatie, of door de onbegrijpelijke formulering van een beding. Een dergelijke aanpak past bij de toenemende aandacht voor de transparantie-eis uit de Richtlijn oneerlijke bedingen. ${ }^{41}$ Het weglaten van essentiële informatie vormt in veel gevallen ${ }^{42}$ een misleidende omissie. ${ }^{43}$

2. Er wordt iets gevorderd op grond van een contract dat onder 'verdachte' omstandigheden is gesloten. De consument ontkent het bestaan van de contractuele rechtsgrond: hij zegt het contract nooit te hebben gesloten of nooit te hebben willen sluiten. Relevante omstandigheden zijn de plaats van sluiting, de leeftijd

36. Telefoonabonnement, r.o. 1-4.

37. Telefoonabonnement, r.o. 6 en 7

38. Telefoonabonnement, r.o. 8 en annotatie C.M.D.S. Pavillon, TvCH 2018/1, p. 52 en 53.

39. Dit was het geval in de zaken Motorverzekering en Telefoonabonnement.

40. Vgl. HvJ EU 18 december 2014, C-449/13, ECLI:EU:C:2014:2464 (CA Consumer Finance): een verklaringsfictie volstaat niet.

41. Zie over deze eis: C.M.D.S. Pavillon, Woekeren met de Richtlijn oneerlijke bedingen, $\mathrm{TvCH}$ 2018/2.

42. Noodzakelijk is wel dat de desbetreffende informatie het besluit van een gemiddelde consument over de transactie aanmerkelijk verstoort of kan verstoren.

43. Zie art. 6:193f BW. Op grond van de bepalingen ter implementatie van de Richtlijn consumentenkrediet (art. 7:59, 7:60 en 7:61 BW) is de nietnaleving van de reclame- en precontractuele verplichtingen bijvoorbeeld een OHP als bedoeld in art. 6:193b BW. In sommige gevallen staat op het schenden van de informatieplicht een aparte (vernietigings)sanctie (art. 6:230n lid 3 BW). In geval van samenloop tussen sancties krijgt de bijzondere sanctie voorrang (vgl. art. 3 lid 4 Richtlijn). van de consument, de aard van het gekochte, enzovoort.

3. Er is sprake van een praktijk als bedoeld in de zwarte lijsten (art. 6:193g en art. 6:193i BW).

De feitelijke context waarin de regeling OHP toepassing heeft, is veelal dezelfde als die waarin de wilsgebreken (of wilsontbreken) doorgaans worden ingeroepen. De gelijkenis met wilsgebreken zorgt ervoor dat de ambtshalve aan de regeling OHP toetsende rechter over een 'drempel' moet. Juist de wilsgebreken vergen veel van de consument in termen van stelplicht en bewijslast. De regeling OHP en bijbehorende voor de consument gunstigere bewijslastverdeling $^{44}$ (art. 6:193 lid 1 en lid 2 BW; zie par. 3.2) contrasteert op dit punt met de wilsgebrekenregeling. Als de regeling $\mathrm{OHP}$ en de ambtshalve toepassing hiervan aan populariteit winnen, zal de betekenis van de wilsgebreken in business2consumer-overeenkomsten naar verhouding afnemen. Zover lijkt het echter nog niet, getuige de geringe betekenis van de regeling OHP in de gepubliceerde rechtspraak.

Indien de rechter een aanknopingspunt vindt in de hem voorliggende gegevens, rijzen twee (sets) vragen. De eerste vraag is hoe sterk het feitelijk 'vermoeden' van een oneerlijke praktijk moet zijn en hoe ver de rechter moet gaan om dit vermoeden nader te substantiëren en te toetsen. Deze vraag speelt ook bij de toetsing van algemene voorwaarden en de toetsing of aan de informatieplichten uit de regeling consumentenkrediet is voldaan. ${ }^{45}$ De tweede vraag is of het aanknopingspunt ook de causaliteit moet betreffen, dat wil zeggen of er pas reden is om ambtshalve te toetsen als de rechter een causaal verband vermoedt tussen de oneerlijke handelspraktijk en het gesloten contract, welk verband nodig is voor de vernietiging ex artikel 6:193j lid $3 \mathrm{BW}$. Wij menen dat het antwoord op deze vraag, omwille van de hanteerbaarheid van de ambtshalve toets, bevestigend luidt (zie par. 3.2). In de volgende paragraaf staan we stil bij de toepassingsvereisten van de regeling en meer in het bijzonder bij de hieraan gekoppelde vernietigingssanctie.

\section{De toepassingsvereisten van artikel 6:193j lid 3 BW}

Om een overeenkomst op grond van artikel 6:193j lid 3 $\mathrm{BW}$ te vernietigen moet sprake zijn van een oneerlijke handelspraktijk (par. 3.1). Voorts is vereist dat de consument onder invloed van de handelspraktijk heeft gecontracteerd (par. 3.2) en dat het contract na 13 juni 2014 is gesloten (par. 3.3). Niet duidelijk is in hoeverre nodig is

44. Zie ook HvJ EU 18 december 2014, C-449/13, ECLI:EU:C:2014:2464 (CA Consumer Finance), waaruit blijkt dat de bewijslastverdeling ten aanzien van de naleving van de informatieplichten uit de Richtlijn consumentenkrediet op de kredietverstrekker rust.

45. Het te verschijnen rapport Ambtshalve toepassing III geeft handvatten wat betreft het tweede deel van de vraag. 
dat de (professionele) mederpartij (par. 3.4) van de consument zich van deze handelspraktijk bedient.

\subsection{Wanneer is sprake van een oneerlijke handelspraktijk?}

\subsubsection{De 'trechter' als toetsingssystematiek}

De regeling OHP is alleen van toepassing op business 2 consumer-handelspraktijken. ${ }^{46}$ Van die regeling gaat volgens vaste rechtspraak geen reflexwerking uit. ${ }^{47}$ Het begrip handelspraktijk dient op zijn beurt ruim te worden opgevat. Hieronder valt ook de eenmalige oneerlijke bejegening van de consument door een handelaar. ${ }^{48} \mathrm{De}$ oneerlijkheid van een praktijk schuilt in de onredelijke (potentiële) impact van die praktijk op het economische gedrag van de gemiddelde consument. De toets of sprake is van een oneerlijke handelspraktijk begint bij de zwarte lijsten (art. 6:193g en 6:193i BW). Staat de handelspraktijk niet op die lijsten, dan bieden de subnormen mogelijk uitkomst: de misleidende handelspraktijk (art. 6:193c BW), de misleidende omissie (art. 6:193d BW) of de agressieve handelspraktijk (art. 6:193h BW). Zo niet, dan kan nog steeds sprake zijn van een oneerlijke praktijk in de zin van de hoofdnorm (art. 6:193b $\mathrm{BW}$ ). Bij de hoofd- en de subnormen moet worden vastgesteld dat de gemiddelde consument door de handelspraktijk een besluit over de transactie neemt of kan nemen dat hij anders niet had genomen. Bij de lijstpraktijken wordt dit verondersteld.

In de twee zaken betreffende de percelen begint de rechtbank conform de vordering van eiser (r.o. 4.8) met een toetsing aan de zwarte lijst en komt tot het oordeel dat van een zwarte praktijk geen sprake is. Vervolgens toetst zij aan de hoofdnorm en stelt vast dat er geen sprake is van een schending van de professionele toewijding (art. 6:193b lid 2 sub a BW) en dat de eiser (dat had moeten zijn: de (gemiddelde consument') niet beperkt is in zijn vermogen om een geïnformeerd besluit te nemen over de aankoop van de grond (art. 6:193b lid 2 sub b BW). Daarmee is volgens de rechtbank ook geen sprake van een misleidende omissie (art. 6:193d BW) of van het weglaten van essentiële informatie in de zin van artikel 6:193f sub e BW. ${ }^{49}$ Het omdraaien van de toetsing aan de hoofdnorm en de subnormen wijkt af van eerdergenoemd trechtermodel. Aantonen dat sprake is van strijd met de professionele toewijding - een zeer open norm is niet nodig als sprake is van een misleidende of agressieve praktijk. ${ }^{50}$ Het is daarom logisch om de hoofdnorm als vangnettoets te zien en als laatste de revue te laten passeren.

46. In de twee zaken betreffende koop van percelen grond (par. 2.1) is niet vastgesteld of sprake is van een consument, maar daarvan lijkt geen sprake.

47. Zie voor een kritisch tegengeluid: Hof Arnhem-Leeuwarden 22 april 2014, ECLI:NL:GHARL:2014:3326, m.nt. C.M.D.S. Pavillon, TvCH 2014/6, p. 286-288.

48. HvJ EU 16 april 2015, C-388/13, ECLI:EU:C:2015:225 (Hatosag/UPC).

49. Koop percelen I, r.o. 4.5 en Koop percelen II, r.o. 4.11

50. HvJ EU 19 september 2013, C-435/11, ECLI:EU:C:2013:574 (CHS Tour Services). Wel dient bij de subnormen te worden getoetst aan het 'besluitcriterium', maar dit blijkt ook uit de wet, daar de deelnormen zelf ook verwijzen naar dit criterium.
Veelal vermeldt het vonnis alleen de toegepaste norm, wat voor de hand ligt indien sprake is van een zwarte handelspraktijk. De kantonrechter geeft in de zaak Hijama-therapeut aan dat vaststaat dat het bedrijf op het moment van de sluiting van de overeenkomst niet beschikte over twee gevoerde keurmerken. Dit vormt een zwarte misleidende handelspraktijk in de zin van artikel 6:193g aanhef en sub b BW. ${ }^{51}$ Van een dergelijk inzoomen op de geschonden norm is evenwel ook sprake bij de subnormen, zoals in de zaak Motorverzekering. ${ }^{52}$ De reisorganisatie geeft niet expliciet op de website aan dat in de algemene voorwaarden uitzonderingen zijn opgenomen op grond waarvan een eigen risico geldt en suggereert het tegenovergestelde. ${ }^{53}$ De rechtbank is van mening dat sprake is van zowel een misleidende praktijk als een misleidende omissie (r.o. 13-16). ${ }^{54}$ Of zij naar de lijsten heeft gekeken, is niet duidelijk. Die lijst wordt in de zaak Pseudo Focwa-lid over het hoofd gezien. Hierin wordt ingezoomd op de subnorm misleidende handelspraktijk, terwijl de desbetreffende praktijk op de zwarte lijst prijkt (vergelijk Hijama-therapeut).

In de door ons bestudeerde zaken valt voorts op dat de maatman van de 'gemiddelde geïformeerde, oplettende en omzichtige consument', die van oudsher kritisch wordt bezien, ${ }^{55}$ de individuele consument geen strobreed in de weg legt. De rechter legt de lat niet zo hoog dat de desbetreffende praktijken niet als oneerlijk worden aangemerkt. ${ }^{56}$

\subsubsection{Samenloopkmesties}

Tussen de regeling OHP en de wilsgebreken kan sprake zijn van samenloop. Echter, een ondernemer die zich bedient van een misleidende handelspraktijk handelt onrechtmatig, terwijl een ondernemer die zich schuldig maakt aan dwaling dit niet per definitie doet. ${ }^{57}$ Heeft de misleide consument schade geleden, dan doet zijn procesvertegenwoordiger er daarom goed aan om de vordering te baseren op een misleidende handelspraktijk omdat daarmee ook de onrechtmatigheid is gegeven.

Met het oog op de mogelijkheid om een contract dat is gesloten onder invloed van een oneerlijke handelspraktijk te vernietigen, rijst de vraag naar de samenloop van de bepalingen uit de regeling OHP met bepalingen uit

51. Hijama-therapeut, r.o. 4.3. Er wordt terecht niet getoetst aan het besluitcriterium. Anders dan bij de hoofd- en subnorm hoeft bij de zwarte lijst niet te worden getoetst of het vermogen van de gemiddelde consument om een geïnformeerd besluit te nemen over de transactie is beperkt. Bij de praktijken op de lijst wordt deze beperking verondersteld.

52. Ook in de zaak Telefoonabonnement grijpt de rechtbank direct naar de subnorm, in casu de misleidende handelspraktijk.

53. Motorverzekering, r.o. 16

54. In deze zaak wordt wel getoetst aan het besluitcriterium, zoals dat hoort bij de toepassing van de subnormen.

55. Zie over de kritiek op de Nederlandse maatman: C.M.D.S. Pavillon, Een doelmatigheidsonderzoek naar de maatstaf van de gemiddelde consument - bespreking proefschrift B.B. Duivenvoorde, MvV 2016/1, p. 27-32.

56. Dat de Nederlandse (hoogste) rechter dit soms wel doet, blijkt bijvoorbeeld uit HR 1 mei 2015, ECLI:NL:HR:2015:1191.

57. Ontleend aan C.C. van Dam in: J. Hijma e.a., Rechtshandeling en Overeenkomst (studiereeks Burgerlijk Recht), Deventer: Kluwer 2016, nr. 175. 
andere consumentenrichtlijnen waaraan geen specifieke sanctie is verbonden. ${ }^{58} \mathrm{Wij}$ denken aan de samenloop met informatie- en transparantieplichten uit de Richtlijnen consumentenrechten en oneerlijke bedingen. In lijn met artikel 3 lid 4 Richtlijn OHP, waarin staat dat in geval van strijdigheid tussen de bepalingen van deze richtlijn en andere communautaire voorschriften betreffende specifieke aspecten van oneerlijke handelspraktijken, laatstgenoemde voorschriften prevaleren, krijgt een specifieke sanctie in geval van samenloop in beginsel voorrang.

Dat sprake is van samenloop tussen richtlijnen volgt uit het feit dat het schenden van bepaalde informatieplichten uit andere consumentenrichtlijnen als een misleidende omissie moet worden aangemerkt (art. 6:193f BW en bijlage 2 Richtlijn OHP). Ontbreekt deze koppeling tussen de schending van de informatieverplichting en de misleidingnorm, dan kan de rechter die koppeling maken door de gebrekkige informatievoorziening te toetsen aan de misleidingnorm uit de regeling OHP. ${ }^{59}$ Dit laatste doet zich voor in de zaak Telefoonabonnement (r.o. 7), waarin het niet informeren van de consument over de duur van de overeenkomst en het ontbreken van de opzegmogelijkheid als misleidende omissie is aangemerkt. Het weglaten van deze informatie vormt tevens een schending van artikel 6:2301 sub $\mathrm{f}$ BW, een informatieplicht uit de Richtlijn consumentenrechten. Aan de schending van artikel 6:2301 BW is evenwel geen aparte sanctie verbonden en dit makt de regeling OHP met bijbehorende vernietigingssanctie een aantrekkelijk beschermingsmechanisme. ${ }^{60}$

In de zaak Motorverzekering is sprake van samenloop met de Richtlijn oneerlijke bedingen. ${ }^{61}$ Het litigieuze beding achtte het eigen risico 'te allen tijden (...) van toepassing als er sprake is van opzet, het niet goed behandelen van je motor, gebrek aan beheersing van de motor, onheil van buitenaf zoals weersomstandigheden, het gebrek aan verkeersinzicht en het niet houden aan aanwijzingen van de tourleaders' (r.o. 6). De reisaanbieder had in zijn reclame-uitingen echter vermeld dat er geen eigen risico gold. Ondanks dat hij hierbij expliciet op de toepasselijke algemene voorwaarden had gewezen, heeft de rechter de voor een 'onaangename financiële verrassing' zorgende clausule vernietigd op grond van artikel 6:193c (de misleidende handelspraktijk) jo. arti-

58. In sommige gevallen staat dan bijvoorbeeld de weg van art. 3:40 lid 2 BW open. Zie voor een uitgebreide bespreking van mogelijke sancties bij een schending van een informatieplicht: L.B.A. Tigelaar, Sanctionering van informatieplichten uit de Richtlijn consumentenrechten (diss. Groningen), Zutphen: Uitgeverij Paris 2017, nr. 294-337.

59. Van belang is wel dat de informatievoorziening als handelspraktijk kan worden aangemerkt.

60. Kanttekening verdient dat niet alle informatieplichten uit deze bepaling zien op onderwerpen die de potentie hebben de wilsvorming van de consument te beïnvloeden; zie hierover Tigelaar 2017, nr. 311. Bij misleidende informatie met betrekking tot herroeping of met betrekking tot de overeenkomst, zoals garantie, zal het causaal verband tussen de oneerlijke handelspraktijk en contractssluiting lastig aan te tonen zijn: de fictieve situatie zonder OHP kan dan immers gunstiger zijn dan de situatie waarin de informatieplicht geschonden is.

61. Richtlijn 93/13/EEG betreffende oneerlijke bedingen in consumentenovereenkomsten (PbEG 1993, L 95/29). kel 6:193j lid 3 BW, met verwijzing naar de uit de Richtlijn oneerlijke bedingen afkomstige transparantieeis uit artikel 6:238 lid 2 BW. ${ }^{62}$ Aan dergelijke verrassende bedingen verbindt die richtlijn geen duidelijke sanctie. $^{63}$

Artikel 6:193j lid 3 BW verwerft in genoemde zaken een plaats als vernietigingsmechanisme van algemene voorwaarden waarover de consument, gelet op de vergaande informatie- en transparantie-eisen uit onder meer de Richtlijn consumentenrechten en de Richtlijn oneerlijke bedingen, niet (voldoende) is geïformeerd. ${ }^{64}$ De contractspraktijk moet rekening houden met het grotere gewicht dat hierdoor komt te rusten op de informatieverstrekking. Is informatie niet verstrekt of is zij onvolledig, onbegrijpelijk of onduidelijk, dan kan dit een misleidende handelspraktijk of omissie opleveren en komt de vernietigingssanctie uit artikel 6:193j lid 3 BW om de hoek kijken. Daarbij moet het wel gaan om informatie die de gemiddelde consument nodig heeft om een geïnformeerd besluit over een transactie te nemen.

\subsection{Causaal verband tussen overeenkomst en praktijk}

De leden 1 en 2 van artikel 6:193j BW komen de consument tegemoet bij het inroepen van de vernietiging. Op basis van lid 1 dient de handelaar desgevraagd de materiële juistheid en volledigheid aan te tonen van de informatie die hij heeft verstrekt. ${ }^{65}$ Lid 2 houdt in dat de oneerlijke handelspraktijk aan de ondernemer wordt toegerekend en keert de bewijslast dienaangaande om. ${ }^{66}$ Daarmee is de consument er echter nog niet. Voor een geslaagd beroep op artikel $6: 193 \mathrm{j}$ lid $3 \mathrm{BW}$ is ook causaliteit vereist. Dat de gemiddelde consument door een handelspraktijk een besluit over de transactie neemt of kan nemen dat hij anders niet had genomen (zie par. 3.1.1), betekent niet dat de individuele consument ook daadwerkelijk door de praktijk is beïnvloed toen hij besloot om te contracteren. Dit laatste moet door de consument worden gesteld en zo nodig bewezen.

Toen in 2008 de oneerlijke handelspraktijk als onrechtmatige daad werd aangemerkt, is gewezen op de bewijsproblematiek die het vereiste causaal verband tussen een oneerlijke handelspraktijk en schade meebrengt. ${ }^{67}$ Wat

62. Motorverzekering, r.o. 15

63. C.M.D.S. Pavillon, De aanpak van verrassende bedingen onder het nieuw BW: de mazen van afdeling 6.5.3 inzake algemene voorwaarden, WPNR 2017/7133.

64. Dergelijke bedingen zijn naar hun inhoud doorgaans niet onredelijk bezwarend, maar veelal 'verrassend'. Door de weg van de misleidende omissie te bewandelen wordt ook voorbij gegaan aan de beperkte mogelijkheid om dergelijke algemene voorwaarden op basis van art. 6:233 sub b jo. art. 6:234 BW (schending van de terhandstellingsplicht) te vernietigen.

65. Verkade 2016, nr. 49. Art. 6:193j lid 1 BW is te herleiden naar art. 12 sub a Richtlijn oneerlijke handelspraktijken.

66. Verkade 2016, nr. 48 en 52.

67. Handelingen II 2007/08, 30928, 14, p. 937, aangehaald door Van Boom 2008, p. 8. Overigens wordt er in dit debat tussen de Tweede Kamer en de minister er - ten onrechte - van uitgegaan dat bij een onrechtmatige-daadsactie geen causaal verband is vereist. Zie voor een illustratie van dit bewijsprobleem: Pseudo Focwa-lid, r.o. 25 en Rb. Limburg 9 mei 2018, ECLI:NL:RBLIM:2018:4295, m.nt. C.M.D.S. Pavillon en L.B.A. Tigelaar, TvCH 2018/4 (Staatsloterij-zaak). In deze individuele 
betreft artikel 6:193j lid $3 \mathrm{BW}$ is vanaf onze kant gepleit voor de invoering van een bewijsvermoeden ten aanzien van het causaal verband tussen oneerlijke handelspraktijk en overeenkomst, welk vermoeden een voorwaarde zou moeten vormen voor de ambtshalve toepassing van de sanctie (zie par. 2.3.3). Dat sprake is van een praktijk die het economische gedrag van de gemiddelde consument verstoort, impliceert naar wij menen dat ook het gedrag van de individuele consument is verstoord. Betoogd is dat het lastig is voor de consument om te bewijzen dat de oneerlijke handelspraktijk redengevend is geweest voor hem om met de ondernemer de overeenkomst te sluiten. ${ }^{68} \mathrm{Klopt}$ dit betoog in het licht van de geraadpleegde uitspraken waarin artikel 6:193j lid $3 \mathrm{BW}$ een rol speelt? ${ }^{69}$

In de zaak Hijama-therapeut legt de consument aan zijn vordering ten grondslag dat hij had afgezien van de cursus als hij had geweten van de valse keurmerken. ${ }^{70}$ De rechter herhaalt dit standpunt in zijn beoordeling ${ }^{71}$ en oordeelt dat de consument succesvol de vernietiging van de overeenkomst kan inroepen, omdat deze als gevolg van een oneerlijke handelspraktijk tot stand is gekomen. ${ }^{72}$ In de zaak Pseudo FOCWA-lid heeft de consument volgens de rechter voldoende gemotiveerd gesteld dat het FOCWA-lidmaatschap voor hem van belang was bij het aangaan van de koopovereenkomst. Dit lidmaatschap brengt namelijk verschillende voordelen mee: aanspraak op twee jaar FOCWA-garantie, kwaliteitswaarborgen en de mogelijkheid om een geschil, zonder hoge kosten, voor te leggen aan een geschillencommissie. ${ }^{73}$ Onder andere na deze vaststelling benadrukt de rechter dat een overeenkomst die als gevolg van een oneerlijke handelspraktijk tot stand is gekomen, vernietigbaar is op grond van artikel 6:193j lid $3 \mathrm{BW} .{ }^{74}$

Ook in de zaak Motorverzekering heeft de consument feiten gesteld die wijzen op het bestaan van het causaal verband: 'Deze strategie is in dit geval effectief gebleken, nu [gedaagde] aangeeft dat zij - hoewel [de reisorganisatie] niet de goedkoopste aanbieder was - de reis juist bij [de reisorganisatie] heeft geboekt vanwege de all-in prijs en het ontbreken van een eigen risico, om onaangename financiële verrassingen achteraf te vermijden. ${ }^{75}$ De rechter koppelt deze stelling echter niet uitdrukkelijk aan artikel 6:193j lid 3 BW. In de zaak Tele-

zaak legde de rechter de bewijslast wat betreft het causaal verband tussen misleidende reclame en schade bij de consument. Overigens zou zelfs bij toepassing van een bewijsvermoeden zoals in de World Onlinezaak de Staatsloterij zijn geslaagd in het leveren van tegenbewijs.

68. Tigelaar 2017, nr. 417. Vgl. HR 27 november 2009, NJ 2014/201 (World Online)

69. In Rb. Limburg 9 mei 2018, ECLI:NL:RBLIM:2018:4295 (Staatsloterijzaak) wordt art. 6:193j lid 3 BW ook ingeroepen, maar is dat artikel nog niet van toepassing (hierna par. 3.4). Deze zaak valt nog onder de voorloper van de OHP: de regeling inzake misleidende reclame. Wij behandelen deze uitpraak daarom slechts zijdelings.

70. Hijama-therapeut, r.o. 3.2.

71. Hijama-therapeut, r.o. 4.2

72. Hijama-therapeut, r.o. 4.4

73. Pseudo Focwa-lid, r.o. 20.

74. Pseudo Focwa-lid, r.o. 21.

75. Motorverzekering, r.o. 15 foonabonnement is door de consument geen beroep gedaan op de regeling OHP. Voor het bestaan van het causaal verband kan mogelijk worden angeknoopt bij zijn verweer 'dat hij in de winkel van T-Mobile heeft begrepen dat hij het abonnement per maand kon opzeggen, nadat hij zich had gemeld voor een anpassing van zijn abonnement'. ${ }^{76}$ Dit doet de rechter echter niet. Hij volstaat met een toetsing aan het (geobjectiveerde) besluitcriterium. De rechtbank merkt gedaagde aan als een 'gemiddelde consument' en concludeert dat hij in die hoedanigheid een besluit over de transactie heeft genomen dat hij anders (mogelijk) niet had genomen. ${ }^{77}$ Dat sprake is van een causaal verband tussen de omissie en het sluiten van de overeenkomst, wordt in deze zaak niet expliciet gesteld door de consument noch vastgesteld door de rechter.

In alle gevallen brengt de consument min of meer duidelijk naar voren dat hij zonder de misleiding niet had gecontracteerd. Slechts in de eerstgenoemde zaken Hijama-therapeut en Pseudo FOCWA-lid gaat de rechter expliciet in op het causale verband. Waarom de rechter dit in de zaken Motorverzekering en Telefoonabonnement niet doet, blijft gissen, te meer omdat artikel 6:193j lid 3 BW dit vereiste duidelijk stelt. Hoewel het bestaan van de causaliteit in deze zaken annemelijk is, is dit niet bij alle misleidende praktijken het geval. Dit blijkt uit de recente uitspraak van de Rechtbank Limburg in een Staatsloterij-zaak waarin schadevergoeding werd gevorderd. ${ }^{78}$ Ook wat betreft het Volkswagenschandaal rijst de vraag of de misleiding over de resultaten van de emissietests de beslissing van individuele consumenten om de auto te kopen daadwerkelijk heeft beïnloed.

Gelet op de eerdergenoemde samenloop met de regeling van de wilsgebreken en de potentiële verdringende rol van de regeling OHP, is van belang dat het causaliteitsvereiste van artikel 6:193j lid $3 \mathrm{BW}$ zorgvuldig wordt toegepast. De vernietigingssanctie mag niet te lichtzinnig worden toegepast. Zo niet, dan kan de kloof tussen wilsgebreken en regeling OHP erg groot worden. Een causaliteitsvermoeden, hoewel dit naadloos ansluit bij de ambtshalve toepassing van de regeling en de noodzaak van een effectieve rechtsbescherming, gaat in dit licht mogelijk te ver. Zou niettemin voor een dergelijk vermoeden worden gekozen, dan dient de wederpartij voldoende ruimte te krijgen om tegenbewijs te leveren. Daarnaast is van belang dat bij de vaststelling of sprake is van een oneerlijke handelspraktijk (zie par. 3.1.1), de 'gemiddelde consument' als maatman wordt gehanteerd.

\subsection{Een toepassingsbereik beperkt in de tijd}

De sanctie uit artikel 6:193j lid 3 BW kan alleen worden toegepast op overeenkomsten die consumenten en 
ondernemingen hebben gesloten ná 13 juni $2014 .{ }^{79}$ In de zaak Koop percelen I wijst de rechter onder andere de vordering van de kweker af, omdat de overeenkomst dateert van vóór 13 juni 2014. ${ }^{80}$ Het overgangsrecht had de rechter in de zaak Motorverzekering er eigenlijk van moeten weerhouden om artikel $6: 193 \mathrm{j}$ lid $3 \mathrm{BW}$ toe te passen. In dit vonnis past de rechter de vernietigingsgrond ambtshalve toe, terwijl de consument de reis heeft geboekt op 26 februari 2013 en dus vóór 13 juni 2014. ${ }^{81}$ Ook in de zaak Pseudo FOCWA-lid is de toepassing van artikel $6: 193 \mathrm{j}$ lid $3 \mathrm{BW}$ onterecht, omdat de auto is gekocht op 21 augustus $2013 .^{82}$ De rechter in de zaak Hijama-therapeut overweegt nadrukkelijk dat de overeenkomst tussen de consument en de ondernemer is gesloten na 13 juni $2014 .{ }^{83}$ Naar aanleiding van de recente door een individuele deelnemer vergeefs ingestelde vordering jegens de Staatsloterij gaat de Rechtbank Limburg uitgebreid in op het beperkte temporele toepassingsbereik van de nieuwe sanctie. ${ }^{84}$

\subsection{Een oneerlijke handelspraktijk van de professionele wederpartij?}

Volgens Geerts zou artikel 6:193j lid 3 BW moeten worden gelezen als: 'een overeenkomst met de handelaar die als gevolg van een door hem gepleegde oneerlijke handelspraktijk tot stand is gekomen, is vernietigbaar'. Zonder deze toevoeging zou de sanctie volgens hem onbillijke gevolgen hebben. ${ }^{85}$ Een korte casus ter illustratie. Stel dat een consument agressief wordt bejegend in een belwinkel van provider $\mathrm{X}$ en zijn abonnement met provider A bij provider Y Provider X komt achter het voorval in af bij provider Y. Provider X komt achter het voorval in de belwinkel en belt met excuses en een mooie aanbieding. De consument wil graag terug naar provider $\mathrm{X}$. Met Geerts zijn wij van mening dat de nieuwe overeenkomst met provider $\mathrm{Y}$ niet kan worden vernietigd op grond van artikel 6:193j lid $3 \mathrm{BW}$. Provider Y heeft part noch deel gehad aan de agressieve handelspraktijk.

In alle besproken zaken is de oneerlijke praktijk door de wederpartij gepleegd. Van een 'onbillijke' toepassing van de vernietigingssanctie is dan ook geen sprake. De valse keurmerken werden gevoerd door de handelaren waar de consument een overeenkomst mee sloot. De reisorganisatie makkte gebruik van de misleidende voorwaarden en reclame. In de zaak met betrekking tot het

79. Art. 79 Overgangswet. Zie over deze bepaling: Rb. Noord-Holland 13 november 2014, ECLI:NL:RBNHO:2014:12536 (Pseudo Focwa-lid), m.nt. M.B.M.Loos, TvCH 2015/2, p. 92.

80. Koop percelen I, r.o. 4.11

81. Motorverzekering, r.o. 3.

82. Pseudo Focwa-lid, r.o. 2, m.nt. M.B.M.Loos, TvCH 2015/2, p. 92. Op dit punt wijst Loos in zijn annotatie. De rechter handelt de zaak uiteindelijk af op grond van non-conformiteit.

83. Hijama-therapeut, r.o. 4.4.

84. Rb. Limburg 9 mei 2018, ECLI:NL:RBLIM:2018:4295, r.o. 4.8

85. Noot P.G.F.A. Geerts onder HvJ EU 16 april 2015, ECLI:EU:C:2015:225 (Hatosag/UPC), IER 2015/33. Zie ook T.M.C. Arons, Van financiële massaproducten en (massa) vernietigingssancties. Vernietiging van overeenkomsten wegens oneerlijke handelspraktijk. Nederlandse toevoeging aan de consumentenrichtlijn, Ondernemingsrecht 2015/104, afl. 15 , p. 526-534

telefoonabonnement heeft T-Mobile in een eigen belwinkel de consument misleid.

Onduidelijk is evenwel hoe ver de voorwaarde strekt dat de oneerlijke handelspraktijk door de mederpartij wordt gepleegd. Wat als deze consument in een 'algemene belwinkel' was misleid? Naar wij menen is de overeenkomst ook dan vernietigbaar. Al heeft de provider zelf niet oneerlijk gehandeld, hij biedt zijn diensten en producten aan via die winkel en zou het risico moeten dragen dat hierbij oneerlijk wordt gehandeld. In de aangehaalde Volkswagen-affaire rijst de omgekeerde vraag in hoeverre (niets vermoedende) professionele verkopers het risico van oneerlijke praktijken van producenten moeten dragen (zie par. 3.2). ${ }^{86}$ Volgens ons kan, mits de causaliteit wordt aangetoond, de koopovereenkomst met een officiële dealer zonder meer worden vernietigd. De niet erkende dealer of garage zou langs de baan van artikel 6:193j lid 2 BW kunnen aantonen dat de misleidende praktijk hem niet kan worden toegerekend. Dan is van een oneerlijke handelspraktijk gepleegd door de wederpartij geen sprake en is vernietiging op de voet van artikel 6:193j lid 3 BW niet mogelijk.

\section{Rechtsgevolgen van een geslaagde toepassing van artikel 6:193j lid 3 BW}

\subsection{Algehele vernietiging}

In de zaak Hijama-therapeut leidt de ambtshalve toepassing van artikel $6: 193 \mathrm{j}$ lid $3 \mathrm{BW}$ tot vernietiging van de overeenkomst. ${ }^{87}$ De rechter verklaart voor recht dat de consument bij brief de overeenkomst rechtsgeldig heeft vernietigd. De betalingen door de consument zijn daarmee onverschuldigd gedaan en het bedrijf is verplicht krachtens artikel 6:203 BW het betaalde bedrag van $€ 500$ terug te betalen aan de consument. ${ }^{88}$ In deze zaak wilde de consument af van de overeenkomst en heeft de restitutie geen nadelige gevolgen voor hem. Het vernietigen van een overeenkomst omdat sprake is van een misleidende omissie is echter niet altijd in het belang van de consument. Denk aan de lening die na de vernietiging terstond moet worden terugbetaald. De remedie ten behoeve van de consument mag zich niet tegen hem keren. ${ }^{89}$ Ook kunnen de algehele vernietiging en bijbehorende afwikkeling onnodig ingewikkeld zijn, zoals in de zaak Motorverzekering. Dan volstaat een partiële vernietiging (art. 3:41 BW).

86. gen van de producent de non-conformiteit bepalen.

87. Rb. Midden-Nederland 30 september 2015, ECLI:NL:RBMNE: 2015:6985 (Hijama-therapeut). In de zaak Pseudo Focwa-lid is niet alleen sprake van een misleidende handelspraktijk, maar ook van nonconformiteit. De rechter geeft aan dat de consument gerechtigd was de overeenkomst buitengerechtelijk te ontbinden (art. 7:22 lid 1 BW) en dat partijen aldus van hun verbintenissen zijn bevrijd.

88. Hijama-therapeut, r.o. 4.4.

89. Vgl. HvJ EU 30 april 2014, C-26/13, NJ 2014/355 (Kàsler). 


\subsection{Partiële vernietiging}

De ambtshalve toepassing van de vernietigingsgrond heeft in de zaak Motorverzekering tot gevolg dat alleen het 'eigen risico'-beding van de reisorganisatie wordt vernietigd en de vordering die op dit beding is gebaseerd wordt afgewezen. De huurovereenkomst inzake de motor blijft verder onaangetast. De misleiding betrof slechts het getroffen beding. Ook in de zaak Telefoonabonnement is gekozen voor een partiële vernietiging van de voorwaarden waarover de consument is misleid. ${ }^{90}$ Vernietigd zijn kennelijk (dit wordt niet geëxpliciteerd in het vonnis) de vaste duur van de overeenkomst en de onmogelijkheid om de overeenkomst tussentijds op te zeggen. De consument heeft als gevolg hiervan de overeenkomst op rechtsgeldige wijze opgezegd. Hij dient de kosten van het abonnement en het gebruik tot aan de datum van de opzegging te voldoen. Het resultaat hiervan is dat van de vordering van $\mathrm{T}$ Mobile niets overblijft en dat deze wordt afgewezen. ${ }^{91}$ In dit geval wordt hetzelfde gevolg bereikt als ware de (sim-only) overeenkomst vernietigd. Echter, als de consument het abonnement nog enige tijd had willen laten doorlopen teneinde dat op een later tijdstip tussentijds op te zeggen, dan was dat ook mogelijk geweest.

In de hiervoor genoemde gevallen vormt de partiële vernietiging een bij de oneerlijke handelspraktijk passende sanctie die, gelet op het belang van de consument, de voorkeur geniet boven een algehele vernietiging. Indien de partiële nietigheid, hoewel passend, niet mogelijk is (omdat de oneerlijke handelspraktijk een kernbeding betreft of omdat zij niet kan worden gekoppeld aan het beding dat tegen de consument is ingeroepen), rijst de vraag welke sanctie moet worden opgelegd. Mogelijk kan de overeenkomst dan worden aangepast of aangevuld. De beperkende werking van de redelijkheid en billijkheid kan ook uitkomst bieden. ${ }^{92}$

\section{Conclusie}

Artikel 6:193j lid 3 BW blijkt een toegankelijke en gebruiksvriendelijke vernietigingsgrond in handen van de consument. Het aantonen van een misleidende handelspraktijk of omissie is, gelet op artikel 6:193j lid 1 en 2 BW, tamelijk eenvoudig. De objectieve maatman noch de vereiste causaliteit tussen oneerlijke handelspraktijk en contractssluiting vormde in de geraadpleegde uitspraken een knelpunt. De vernietigingsmogelijkheid bleek hierin een belangrijke opstap om tot een passende oplossing te komen in een consumentengeschil. Het bevreemdt enigszins dat de inmiddels vier jaar oude sanctie geen grotere rol speelt in de praktijk.

Als de goede hanteerbaarheid van de sanctie wordt bevestigd, zal de belangstelling hiervoor waarschijnlijk toenemen. Uit de geanalyseerde rechtspraak blijkt dat de rechter een vooraanstaande rol speelt bij de toepassing van artikel 6:193j lid $3 \mathrm{BW}$. Hij is doorgaans degene die het initiatief neemt tot toepassing van de sanctie. Hiermee is de doeltreffende en afschrikwekkende werking van artikel 6:193j lid 3 BW - dat naar verwachting een Europees achtergrond zal krijgen - gewaarborgd. De rechter moet bij de toetsing aan de regeling OHP en de toepassing van de vernietigingsgrond echter ook de nodige evenredigheid betrachten (art. 13 Richtlijn OHP). De sanctie mag niet verder gaan dan nodig. Dit vergt dat de rechter oog houdt voor het feit dat voor toepassing van de sanctie, behalve een oneerlijke handelspraktijk jegens de 'gemiddelde consument', ook een causaal verband wordt vereist tussen oneerlijke handelspraktijk en overeenkomst. De handelaar moet voorts voldoende gelegenheid krijgen om zich tegen toepassing van artikel 6:193j lid $3 \mathrm{BW}$ te verweren. Dit betekent dat de rechter hem in geen geval met die toepassing mag overvallen.

Om de vernietiging op grond van artikel 6:193j lid 3 BW te voorkomen dienen handelaren zorg te dragen voor eerlijke, volledige en duidelijke informatieverstrekking aan consumenten voorafgaand, tijdens én na de sluiting van de overeenkomst. Daarnaast dienen zij zich te onthouden van agressieve handelspraktijken. Lezing van de regeling OHP strekt tot aanbeveling. 